\title{
Osittaislaidunnuksen vaikutus lehmien tuotokseen ja hyvinvointiin
}

Auvo Sairanen ${ }^{1)}$, Jenni Hakosalo ${ }^{2)}$, Perttu Virkajärvi ${ }^{1)}$, Jaakko Mononen ${ }^{2)}$, Risto Kauppinen ${ }^{3)}$, Hannele Khalilii' ${ }^{4}$, Leena Ahola $^{2)}$, Heli Lindeberg ${ }^{2)}$

1)MTT Pohjos-Savon tutkimusasema, 71750 Maaninka, etunimi.sukunimi@mtt.fi

2)Kuopion yliopisto, PL 1627, 70211Kuopio, etunimi.sukunimi@.uku.fi

3)Pohjois-Savon ammattikorkeakoulu,74100Iisalmi, risto.kauppinen@pspt.fi

4) MTT Eläinravitsemus, 31600 Jokioinen, hannele.khalili@mtt.fi

\section{Johdanto}

Lypsykarjatilojen koon kasvaessa kokoaikaisen laiduntamisen järjestäminen karjalle vaikeutuu, sillä usein laitumia ei ole tarpeeksi tai niiden etäisyys navetasta on liian suuri. Vaikka laiduntaminen on edullinen kesäruokintavaihtoehto, ovat yhä useammat tilat siirtymässä kokoaikaiseen sisäruokintaan. Perinteisen kokoaikaisen laiduntamisen ja sisäruokinnan rinnalle tarvitaankin vaihtoehtoisia ruokintamuotoja, jotta tuottajien ei tarvitsisi luopua karjan laiduntamisesta kokonaan. Kesäajan maidontuotannon määrä on noin 700 milj litraa. Prosentuaalisesti pienetkin muutokset tuotannon kokonaismäärässä tai maitolitran tuotantokustannuksessa vaikuttavat merkittävästi tuotantomäärään ja taloudelliseen tulokseen. Kesäajan maidontuotantoa tulisi tällä hetkellä lisätä ja talvikaudella vastaavasti pienentää, koska keväällä nestemäisten maitotuotteiden kysyntä alittaa tuotannon ja vastaavasti etenkin loppukesällä maitoa joudutaan siirtämään kannattavammasta juustontuotannosta nestetuotteiden myyntiin.

Vuonna 2006 voimaantulevan eläinsuojeluasetuksen (396/1996) mukaan lehmien ja hiehojen on päästävä kesäaikaan laitumelle tai niille on järjestettävä muu tarkoituksenmukainen tila liikuntaa varten. Tällaisena tilana voidaan ymmärtää esimerkiksi jaloittelutarha. Laiduntaminen kuuluu lehmien lajinmukaiseen käyttäytymiseen ja tämän vuoksi katsotaan, että laiduntaminen on lehmien hyvinvoinnin kannalta jaloittelutarhaa parempi vaihtoehto. Tässä tutkimuksessa tarkoituksena on verrata säilörehuruokinta + tarhaulkoilutuksen ja säilörehuruokinta + osittaislaidunnuksen vaikutusta eläinten hyvinvointiin ja maitotuotokseen. Osittaislaidunnuksessa vähäisempi laidunala riittää koko karjalle ja edullinen laidunrehu saadaan käyttöön myös suurella karjakoolla. Tutkimukseen on valittu yölaidun, koska yökauden laidunnusaika on käytännössä päiväkautta pidempi ja yölaidunnuksen avulla vältetään mahdollisten helteiden haitalliset vaikutukset syöntiin ja lämpöstressiin.

\begin{abstract}
Aineisto ja menetelmät
Tutkimus suoritettiin laidunkauden 2003 aikana (25.5. - 31.8) MTT:n Pohjois-Savon tutkimusasemalla Maaningalla. Tutkimuksen aineistona oli satunnaistettujen lohkojen kokeen mukaisesti yhteensä 34 holstein-friisiläistä lypsylehmää, joista 30 oli mukana käyttäytymisseurannassa ja hyvinvointiparametrien määrityksessä. Kaikkien koelehmien päivittäinen väkirehuannos oli 9 kiloa jaettuna neljä kertaa päivässä. Käsittelynä kokeessa oli laidunnusaika: puolet lehmistä oli sisäruokinnassa jatkuvasti (sisäruokintaryhmä) ja toinen puoli laidunsi 12 tuntia yökaudella (laidunryhmä). Päivällä laidunryhmä sai vapaasti säilörehua ja yökaudella tarjolla olevan laitumen määrä oli vakioitu $13 \mathrm{~kg} \mathrm{ka/lehmä/vrk.} \mathrm{Tarjolla} \mathrm{olevan} \mathrm{laitumen}$ määrä arvioitiin kolme kertaa viikossa Stocdale -menetelmällä ja kerran kuussa tapahtuneen syönninmääritysjakson (intensiivijakso, 7 vrk) aikana päivittäin. Sisäruokintaryhmä ulkoili päivittäin $2 \mathrm{~h}$ betonipohjaisessa jaloittelutarhassa. Tarhassa eläimille oli tarjolla vettä ja suolakivi, mutta ei rehua. Sisälläoloaikana molemmat ryhmät olivat jatkuvasti kytkettyinä parressa. Kokeessa mitattiin maitotuotos, rehunkulutus, sorkkahoitojen määrä, liikkuvuus kävelytystestin avulla, lihaskunto, kortisoli stressin indikaattorina sekä käyttäytyminen. Tässä kirjoituksessa säilö- ja laidunrehun laatutiedot perustuvat Valion NIR -analyysiin. Käyttäytymisseurannan osalta kaikki tiedot eivät ole vielä käytettävissä.

Maitotuotos mitattiin päivittäin ja maidon pitoisuudet intensiivijaksoilla kolmena peräkkäisenä päivänä (aamu + ilta) sekä jaksojen välillä yhtenä päivänä. Laidunrehun syönti mitattiin intensiivijaksojen aikana määräalaniittomenetelmällä. Sorkkahoito tehtiin ennen laidunkautta ja laidunkauden jälkeen, hoitokoodit kirjattiin sorkanhoitoraporttiin. Lehmien liikkuvuuden arvioinnin suoritti kolme toisistaan riippumatonta henkilöä viikoittain arviointiasteikolla 1-5. Asteikossa 1 tarkoittaa virheetöntä seisomaasentoa ja ongelmatonta liikkumista ja 5 huomattavia ongelmia tai kyvyttömyyttä liikkua (Manson ja Leaver 1988). Lihaskunnon arviointia varten lehmiä videoitiin $12 \mathrm{~h}$ jakso ja makuulle asettautumiseen kulunut aika mitattiin (Herlin 1994). Menetelmässä oletuksena on, että hyväkuntoisten lehmien lihasten hallinta on parempi ja makuulle asettautumisaika pienempi verrattuna heikkokuntoisiin lehmiin. Lehmien
\end{abstract}


pitkäaikaisen stressin fysiologisena mittarina käytettiin plasman peruskortisolitasoa sekä kortisolitasoa ACTH - annostuksen jälkeen. Kortisolin määrityksessä heinäkuun lopussa lehmiltä otettiin ensin verinäyte (0 h näyte) ja niille annettiin sen jälkeen pistoksena $\mathrm{ACTH}: t a$ (adrenokortikotrooppinen hormoni: Synacthen Depot $0,04 \mathrm{ml} / \mathrm{kg} \mathrm{W}^{0.75}$, i.m.). Lehmistä otettiin uudet verinäytteet $1,5 \mathrm{~h}, 3 \mathrm{~h}$ ja $5 \mathrm{~h} \mathrm{ACTH-}$ annostuksen jälkeen. Kaikista verinäytteistä analysoitiin plasman kortisoli. Kuvaileva käyttäytymisseuranta tehtiin videoimalla lehmiä parressaoloaikana $24 \mathrm{~h}$ jaksoissa kerran ennen laidunkautta ja heinäkuussa. Videoinnin kanssa samanaikaisesti suoritettiin lehmien tarkkailu suorana seurantana sekä jaloittelutarhassa että laitumella.

\section{Tulokset ja niiden tarkastelu}

Yölaidunryhmän maitotuotos oli kokeen aikana keskimäärin 3,9 kiloa säilörehuryhmää suurempi (taulukko 1). Laidunryhmän tuotosetu ilmeni heti laitumelle laskun jälkeen ja tuotosero suureni kesän edetessä. Maidon valkuaispitoisuuteen käsittelyillä ei ollut eroja, mutta laiduntaminen laski maidon rasvapitoisuutta. Maidon valkuais/rasvasuhteen lisääntyminen on taloudellisesti kannattavaa etenkin mikäli maitokiintiöt rajoittavat tilan tuotantoa. Kokeessa mitattu tuotosero on mahdollista myös maatiloilla, mutta se edellyttää tilalla hyvin toimivaa laidunkiertoa. Laitumen massan täytyisi pysyä välillä 2000-3500 kg ka/ha ja vedensaanti on oltava turvattu. Osittaislaiduntamisen yksi etu Suomen vaihtelevissa nurmenkasvuolosuhteissa kokoaikalaiduntamiseen verrattuna on laidunkierron joustavuus; heikon nurmenkasvun aikana lehmät voidaan pitää säilörehuruokinnalla ja laidunta annetaan vain toteutuvan nurmen lisäkasvun mukainen määrä. Käytännössä lehmille voi pitää muutaman päivän taukoa laiduntamisessa ilman että ruokinnan muutoksista olisi haittaa maitotuotokseen tai lehmien hyvinvointiin. Laidunryhmän kuiva-ainesyönti oli 1,7 kiloa suurempi verrattuna sisäryhmään, mikä selittää havaittua maitotuotoseroa. Laitumen energia-arvo oli lisäksi suurempi kuin säilörehun, joten energian kokonaissaanti lisääntyi enemmän kuin kuiva-aineen syönti. Osa lisääntyneestä energiansaannista ohjautui elopainon nousuun. Koeaineiston pienuudesta johtuen johtopäätöksiä lehmien tiinehtyvyydestä ei voi tehdä, mutta teoreettisesti voisi olettaa laiduntavien lehmien parantuneella energiataseella olevan positiivista vaikutusta lehmien hedelmällisyyteen.

Kokeessa käytettyjen ensimmäisen korjuukerran säilörehujen käymislaatu oli hyvä (pH 3,8-3,9). Syötössä ollut säilörehuerä vaihtui kesä-heinäkuun vaihteessa ja samalla rehun energia-arvo huononi 0,94 ry $/ \mathrm{kg} \mathrm{ka} 0,88 \mathrm{ry} / \mathrm{kg}$ ka. Loppukesän säilörehun NIR -analyysiin perustuva energia-arvo on poikkeuksellisen matala kohtuullisen aikaisesta korjuuajankohdasta huolimatta (niitto 16.6.2002). Heikko energia-arvo selittää osaltaan lisääntynyttä tuotoseroa loppukesällä alkukesään verrattuna. Väkirehun tuotosvaste yli 10 kilon väkirehumäärillä on aikaisemmissa tutkimuksissa ollut luokkaa 0,5 kiloa maitoa yhtä lisäväkirehukiloa kohti (Huhtanen 1988, Sairanen 1999). Tämän perusteella voidaan olettaa, että kokeen mukaisella säilörehulla laidunryhmän 3,9 kilon tuotoseron kiinnisaamiseen sisäryhmä tarvitsisi yli $8 \mathrm{~kg}$ väkirehua kokeessa käytetyn 9 kilon lisäksi. Täytyy ottaa myös huomioon, että väkirehulisäys noudattaa suurilla määrillä vähenevän lisätuoton lakia eli yli 15 kilon väkirehutäydennyksellä oletettua 0,5 kilon tuotosvastetta ei saavuteta.

Taulukko 1. Säilörehu- ja laidunruokintaryhmien väliset erot rehunkulutuksessa ja maitotuotoksissa.

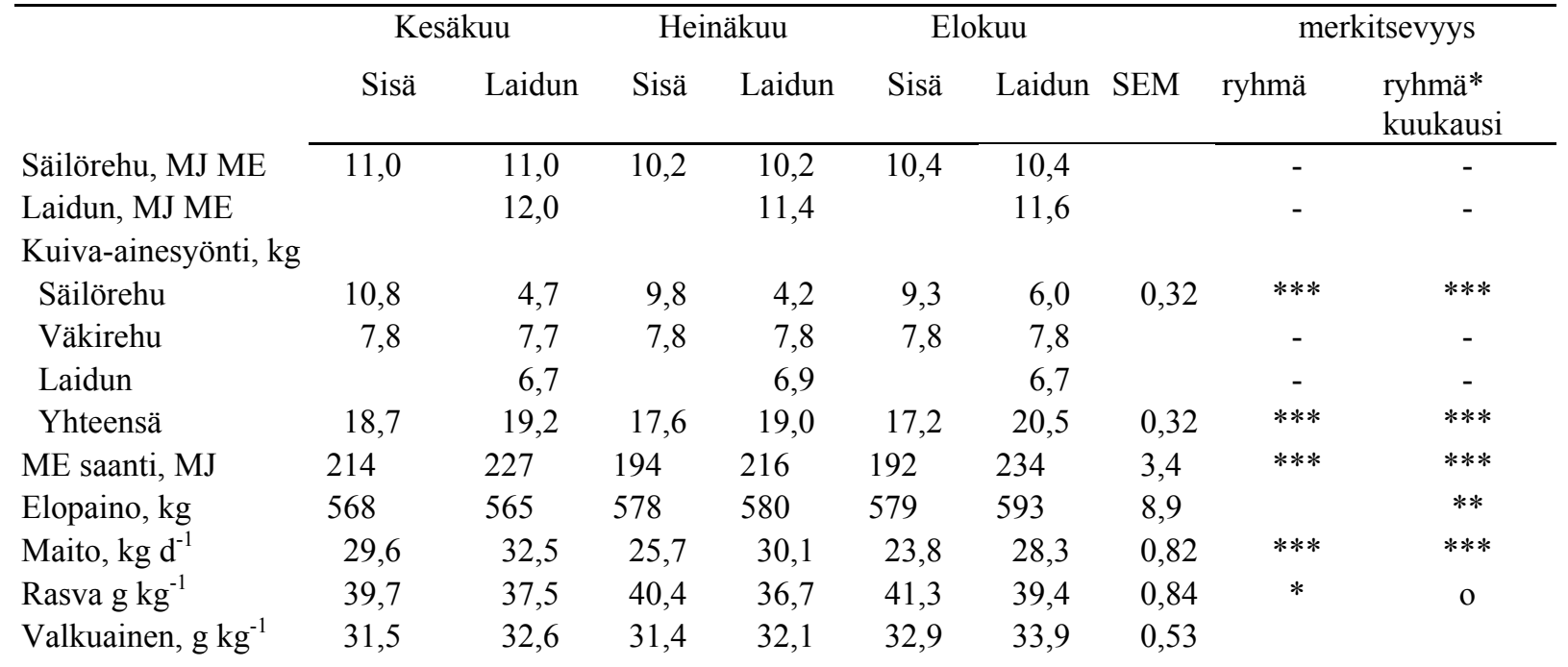


Hyvinvointiparametrien osalta ryhmien väliset erot eivät olleet selkeitä. Aikaisemmissa tutkimuksissa laiduntamisella on ollut vaihteleva merkitys lehmien terveyteen. Tässä kokeessa ryhmien välillä ei havaittu eroja maidon solupitoisuudessa eikä kävelytystestin avulla suoritetussa liikkuvuuskuntoarviossa kesän aikana. Kävelytystestinä (asteikolla 1-5) suoritetussa liikkuvuuden arvioinnissa luokan 1 osuus koko aineistossa nousi hieman loppukesällä (kesäkuu $52 \%$, heinäkuu $60 \%$, elokuu $56 \%$ ), samoin laiduntavalla ryhmällä luokan 3 osuus hieman pieneni. Yleisesti voidaan todeta, että muutoksen kesän kuluessa olivat vähäisiä eikä ryhmien välille tullut eroa.

Toukokuussa tehdyssä sorkkahoidossa haitallisia muutoksia (valkoviivan repeämä, vertymä, sorkkakuume, haavauma tai ihotulehdus) rekisteröitiin laidunryhmälle $11 \mathrm{kpl}$ ja sisäryhmälle $10 \mathrm{kpl}$. Kesän aikana osa sorkkavaivoista parani, mutta myös uusia tapauksia ilmeni. Syyskauden sorkkahoidossa rekisteröitiin hoitokoodeja laidunryhmälle 7 ja sisäryhmälle 9 eli kesän aikana sorkkakunnossa laidunryhmän sorkkakunto parani hieman sisäryhmää enemmän.

Lehmien lihaskuntoa arvioitiin makuulle asettautumisajan perusteella. Sisäryhmän lehmillä kului keskimäärin 24,1 sekuntia makuulle menoon ja vastaavasti laidunryhmällä aikaa kului 22,5 sekuntia (P > 0.1). Kaksi sisäruokintaryhmän lehmää ja yksi yölaidunryhmän lehmä jätettiin huomioimatta laskettaessa makuulle menoon käytetyn ajan keskiarvoa, koska näillä oli joko huomattavia vaikeuksia tai muista poikkeava tapa asettua makuulle. Mitattujen lukujen perusteella laiduntamisesta ei ollut hyötyä lihaskuntoon liikkeiden hallinnan parantumisen kautta.

Stressin fysiologisena mittarina käytettiin plasman peruskortisolitasoa sekä kortisolitasoa ACTH pistoksen jälkeen (kuva 1). Stressitilanteessa aivolisäkkeen erittämä ACTH lisää lisämunuaisen kuorikerroksen kortisolituotantoa. Jatkuvasti koetut stressaavat tilanteet voivat nostaa plasman peruskortisolitasoa ja herkistää lisämunuaisen kuorikerroksen vastetta ACTH:lle. Peruskortisolitaso ennen ACTH annosta oli laidunryhmällä hieman pienempi; $12,3 \mathrm{nmol} / 1$ vs $20,0 \mathrm{nmol} / 1(\mathrm{P}=0.18)$. ACTH annoksen jälkeen laidunryhmän lehmien kortisolitasot nousivat hieman sisäryhmää suuremmiksi, mutta ero ei ollut tilastollisesti merkitsevä. Molemmissa ryhmissä ensikoiden plasman kortisoli oli matalampi kuin useasti poikineilla ( $199 \mathrm{nmol} / 1$ vs $169 \mathrm{nmol} / 1, \mathrm{p}=0,08)$. Mitattujen arvojen perusteella sisäryhmä ei ollut ulkoryhmää stressaantuneempi.

Kuva 1. Plasman kortisolin perustaso $(0 \mathrm{~h})$ ja ACTH-annoksen $\left(0,04 \mathrm{ml} / \mathrm{kg} \mathrm{W}^{0.75}\right)$ vaikutus plasman kortisolipitoisuuteen heinäkuussa yölaiduntavilla (Laidun) ja sisällä pidetyillä (Sisä) lypsylehmillä.

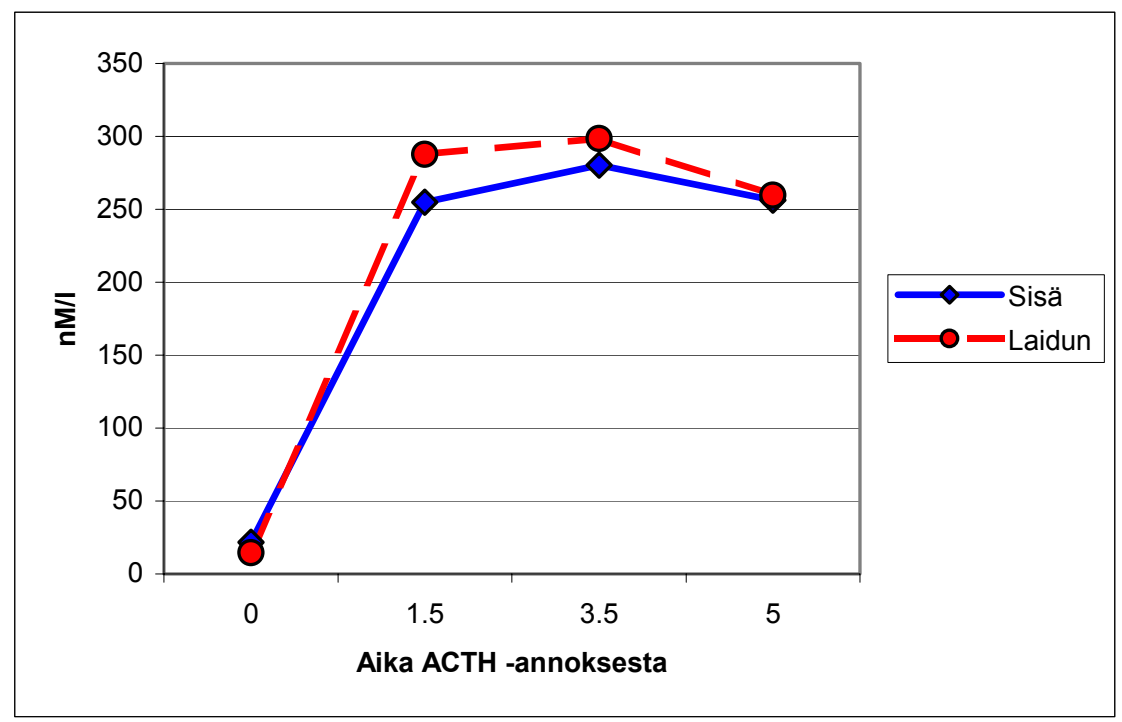

Lehmien käyttäytymistä seurattiin navetassa ympärivuorokautisella videoinnilla ennen laidunkautta ja laidunkaudella heinäkuussa. Tietojen purku on kesken, joten tässä yhteydessä esitetään osa tuloksista kuvailevana tietona. Molempien ryhmien sisälläoloajan käyttäytymishavainnot jaettiin pääkäyttäytymisiin (nuokkuu, syö, juo, märehtii, seisoo, makaa) sekä häiriökäyttäytymisiin. Oraalisten häiriökäyttäytymisten määrä (kielen pyöritys, rakenteiden pureskelu) oli hyvin vähäinen. Näiden havaintojen lukumäärä laski sisäryhmässä toukokuun 42 havainnosta heinäkuun 24 havaintoon ja laidunryhmällä vastaavasti 
toukokuun 55 havainnosta heinäkuun 9 havaintoon. Kokonaishavaintojen määrä molemmille ryhmille oli toukokuussa 4160 ja heinäkuussa 1450. Heinäkuun pienempi määrä johtuu siitä, että tarkastelussa oli mukana ainoastaan ne havainnot jolloin lehmät olivat parressa samanaikaisesti.

Pääkäyttäytymisten osalta syömiseen kulunut aika (ilmaistuna prosentteina kokonaishavainnoista) oli sisäryhmällä laidunkaudella suurempi verrattuna toukokuuhun ( $22 \%$ vs $32 \%$ havainnoista). Laidunryhmällä vastaavaa ilmiötä ei ollut. Syömiseen käytetty aika väheni sisäryhmällä selvimmin makuulle käytetystä ajasta. Seisomiseen käytetty aika lisääntyi molemmilla ryhmillä toukokuun keskimäärin 18 prosentista laidunkauden 23 prosenttiin havainnoista. Jaloittelutarhassa ja navetassa lehmät märehtivät makuullaan ja seisten, mutta laitumella lähes poikkeuksetta makuulla. Seisaallaan märehtiminen saattoi olla seurausta makuulle menon vaikeudesta ja makuualustan epämukavuudesta parressa ja jaloittelutarhassa (betonialusta). Tutkimusnavetan parsirakenne on poikkeuksellinen eikä mahdollista vapaata pään liikkumista ruokintapöydälle.

Laitumella lehmät ovat rauhallisemman oloisia kuin navetassa ja tarhassa. Esimerkiksi painon vaihtaminen jalalta toiselle paikallaan seistessä oli laitumella huomattavasti harvinaisempaa kuin parressa ja jaloittelutarhassa. Laitumella lehmät kävelivät syödessään, mutta tarhassa vastaavaa liikkumistarvetta ei ollut, joten jaloittelun määrä oli suhteellisesti vähäisempää. Jonkinlainen liikkuminen oli kuitenkin ilmeisesti tarpeen, joten laitumella ruoanhakukäyttäytymiseen liittyvä kävely korvattiin parressa ja jaloittelutarhassa paikoillaan keinumisella ja tepastelulla. Jaloittelutarhassa oli jossain määrin myös tutkiskelevaa käyttäytymistä (juomakuppi, toiset lehmät) ja siihen liittyvää liikkumista. Jaloittelutarhassa lauman sisällä oli myös paljon kahinointia ja toisten puskemista laidunoloihin verrattuna. Ilmeisesti syöminen on myös ajanvietettä lehmille ja mikäli rehua ei ole tarjolla, aika käytetään arvojärjestyksen selvittelyyn tai leikkitappeluihin.

\section{Johtopäätökset}

Osa-aikainen laiduntaminen nosti selvästi maitotuotosta verrattuna kokoaikaiseen säilörehuruokintaan. Samaan tuotostasoon päästäkseen säilörehuryhmä olisi vaatinut huomattavan suuren väkirehumäärän lisäyksen joten maitolitran tuotantokustannus on laiduntamattomalla ryhmällä korkeampi. Tulokset osoittavat, että kokonaisrehuntarpeeseen verrattuna pienikin laidunala kannattaa hyödyntää. Osaaikalaidun on lisäksi Suomen vaihtelevissa nurmen kasvuolosuhteissa joustava tapa laiduntaa verrattuna kokoaikalaidunnukseen. Laiduntamisesta ei ollut merkittävää etua eläinten hyvinvoinnille, jota mitattiin sorkkaterveyteen, käyttäytymiseen, fyysiseen kuntoon ja lisämunuaisen kuorikerroksen toimintaan liittyvillä muuttujilla. Tämä ei sulje pois sitä, että mahdollisuus vapaampaan lajityypilliseen käyttäytymiseen saattaa olla edullista eläinten hyvinvoinnin kannalta.

\section{Kirjallisuus}

Manson, F.J. \& Leaver, J.D. 1988. The influence of concentrate amount on locomotion and clinical lameness in dairy cattle. Anim. Prod. 47: 185-190.

Herlin A.H. 1994. Effects of tie-stalls or cubicles on dairy cows in grazing or zero-grazing situations. Dissertation, Swedish University of Agricultural Sciences. Uppsala, Sweden.

Huhtanen, P. 1988. Supply of nutrients and productive responses in dairy cows given diets based on restrictively fermented silage. Agric. Food Sci. Finl. 7: 219-250.

Sairanen, A., Nousiainen, J.I. \& Khalili, H. 1999. Korkean väkirehumäärän vaikutus maitotuotokseen ja tuotannon kannattavuuteen. In: Mitä Suomi syö - ja millä hinnalla? : Agro-Food '99, Tampere 2.-4.2.1999, Tampere-talo. Helsinki: Agro-Food ry/Agronomiliitto ry. p. P7. 